\title{
KEARIFAN LOKAL SUKU SASAK SEBAGAI MODEL PENGELOLAAN KONFLIK DI MASYARAKAT LOMBOK
}

\author{
(LOCAL WISDOM OF SASAK TRIBE AS A MODEL FOR LOMBOK SOCIETY \\ CONFLICT MANAGEMENT)
}

Muhammad Harfin Zuhdi

Dosen Fakultas Syari'ah UIN Mataram

Pos-el: harfin72@gmail.com

Diterima: 9 April 2018; Direvisi: 9 Mei 2018; Disetujui: 21 Mei 2018

\begin{abstract}
Abstrak
Kearifan lokal sebagai suatu kekayaan budaya yang mengandung nilai pandangan, kebijakan, dan kearifan hidup masyarakat dalam banyak ragam variannya, seperti tercermin dalam konsep krama, sesenggak. perteke, atau lelakaq. Namun saat ini kearifan lokal masih belum difungsikan secara optimal, padahal kearifan lokal dapat dijadikan rujukan sebagai model dalam pengelolaan konflik dan masalah sosial di masyarakat. Keterlibatan kearifan lokal dapat diupayakan melalui pembangunan perdamaian untuk mencegah dan melokalisir konflik di masyarakat, karena melibatkan kearifan lokal terbukti mampu mempertahankan harmoni sosial. Artikel ini berupaya mendeskripsikan kearifan lokal suku Sasak dengan pendekatan kualitatif berbasis content analisis. Dalam upaya pengelolaan konflik harus ada keterlibatan tokoh agama dan tokoh adat dalam mendorong hadirnya peningkatan apresiasi masyarakat terhadap kearifan lokal. Oleh karena itu, untuk menjadikan kearifan lokal sebagai model dalam pengelolaan konflik, maka perlu direvitaliasi dan disosialisasikan secara sistematis dan massif sehingga dapat fungsional sebagai model pengelolaan konflik di masyarakat Lombok. Pendekatan multikultural berbasis kearifan lokal ini merupakan model penting yang dapat dimanfaatkan untu pngelolaan konflik di wilayah ini.
\end{abstract}

Kata kunci: konflik, kearifan lokal suku Sasak, pendekatan multikultural, pengelolaan konflik

\begin{abstract}
Local wisdom can be defined as a local cultural treasure that contains the values of life policy, life viewpoints, and living wisdom. Local wisdom not only applied locally to a particular culture or ethnic, but also to be a cross-cultural or cross-etnical known as the concept of Bhineka Tunggal Ika (Unity in Diversity) in which there are teachings of mutual assistance, tolerance,
\end{abstract}


hard work, and mutual respect. Local wisdom can be used as a reference in solving problems in the community.In the related reconciliation efforts, it was revealed that there was the involvement of religious and traditional leaders in encouraging the enhancement public appreciation of local wisdom. The local wisdom of the Sasak tribe varies widely, as reflected in the concept of krama, sekenggak. perteke, or lelakaq. Sasak local wisdom needs to be revitalized and socialized systematically and synergistically by traditional leaders, religious leaders and stakeholders in the region to function as a model of conflict management in Lombok society. This multicultural approach based on local wisdom is an important model that can be utilized to minimize conflicts in the region.

Keywords: conflict, local wisdom of Sasak tribe, multicultural approach, conflict resolution

\section{Pendahuluan}

Pulau Lombok didiami oleh sejumlah suku dengan budaya, agama, ras dan gologan yang berbeda. Perbedaan tersebut telah dapat bernilai positif bagi pengembangan masyarakat setempat namun juga mengandung nilai negatif, yakni dapat menjadi dasar pemicu terjadinya konflik. Kemajemukan tersebut merupakan suatu tantangan besar bagi pemerintah dan masyarakat dalam mempertahankan kondisi daerah agar tetap aman dan tidak terjadi konflik yang dapat merugikan banyak pihak.

Selama ini, pulau Lombok terkenal sebagai pulau yang aman dan nyaman untuk ditempati sehingga menjadi primadona tujuan destinasi wisata nasional maupun internasional. Namun, dalam dua dekade terakhir, realitas harmoni Indonesia kerap terkoyak oleh serangkaian konflik berbau kekerasan yang marak merebak di berbagai daerah, termasuk di Lombok, Provinsi Nusa Tenggara Barat. Selain meyebabkan jatuhnya korban jiwa yang tak sedikit, konflik juga mengakibatkan dampak sosial yang luar biasa. Berbagai konflik komunal ini bukan hanya sangat mengganggu stabilitas nasional, tetapi juga mengancam integrasi bangsa. Inilah sebetulnya tantangan terberat bangsa Indonesia sebagai bangsa yang tersusun secara multikultur, multietnik, dan multiagama yang rapuh dan rentan jatuh dalam perpecahan jika bangsa ini gagal mengelolanya secara baik.

Untuk kasus Nusa Tenggara Barat, fenomena konflik kekerasan telah menunjukkan intensitasnya, baik dalam bentuk konflik horizontal antarwarga, konflik suatu golongan keagamaan dengan masyarakat sekitarnya, dan yang masih segar dalam 
ingatan masyarakat adalah apa yang terjadi di pesantren Umar bin Khattab (UBK) di Bima. Demikian juga, fenomena benih-benih paham keagamaan radikal dan potensi konflik komunal masih bercokol di sejumlah tempat di pulau Lombok, seperti konflik Monjok versus Karang Taliwang.

Lebih jauh, dalam konteks kelompok-kelompok masyarakat yang berbeda agama, jika dicermati pergerakannya, meski di permukaan nampak rukun dan tenang, namun di bawah permukaan sesungguhnya terjadi persaingan dan perebutan pengaruh dan pengikut. Lebih jauh, konflik sosial akibat sara telah menimbulkan kerugian besar bagi masyarakat maupun pemerintah, dari sisi materiel yakni hancurnya infrastruktur yang ada dan hilang/rusaknya harta kekayaan. Lebih dari itu, konflik juga berdampak pada sosio-psikologik dan sosio-kultural yang memprihatinkan bagi masyarakat di mana konflik terjadi. Konflik sosial tersebut telah menimbulkan depresi sosial, traumatik, keinginan balas dendam, dan menguatnya fenomena social tention, cultural disintegration dan rendahnya social trust terhadap pemerintah maupun terhadap kelompok masyarakat. Tentunya hal itu tidak diinginkan terulang kembali. Oleh karena itu, dibutuhkan suatu bentuk upaya preventif agar tidak terulang serta penanganan permasalahan yang timbul dengan baik secara proporsional, terutama dengan pendekatan kearifan lokal.

\section{Kerangka Teori}

\subsection{Kearifan Lokal Suku Sasak}

Kedamaian dan keharmonisan sebetulnya merupakan kultur dominan masyarakat Sasak. Sejumlah idiom yang dikenal di lingkungan masyarakat Sasak sangat dekat dengan orientasi kedamaian. Konsep ajinin yang secara harfiah berarti saling menghormati, reme, rapah, regen yang berarti suka memberi, memilih situasi aman damai dan mendukung toleransi menambah khazanah kearifan lokal masyarakat Lombok dalam menjalani relasi sosial.

Sejak masa lampau, etnis Sasak telah mengenal wadah yang menjadi induk dalam kehidupan bermasyarakat mereka yang mengatur tentang pedoman hidup warga masyarakat, dan tempat mereka mencari rujukan untuk menetapkan sanksi atas terjadi pelanggaran dalam tata pergaulan komunitasnya. Wadah itu dikenal 
dengan istilah krama. Konsepsi ini teraktualisasikan atau terjabarkan dalam kehidupan sehari-hari masyarakat Sasak sejak masa lampau sehingga pelaksanaan dari konsepsi kultural itu telah menjelma menjadi berbagai elemen atau unsur yang tidak terpisahkan.

$\begin{array}{rrr}\text { Secara } & \text { konseptual, krama } \\ \text { merupakan institusi adat yang }\end{array}$
memayungi kearifan lokal yang terdiri atas dua macam, yaitu krama sebagai lembaga adat dan krama sebagai aturan pergaulan sosial. Ajikrama terdiri atas kata, aji yang berarti harga atau nilai dan krama yang berarti 'suci' dan terkadang berarti 'daerah atau kesatuan penduduk dalam suatu wilayah dalam suatu daerah adat'. Dengan demikian, ajikrama lambang adat, artinya nilai suci dari suatu strata sosial adat Sasak berdasarkan wilayah adatnya.

\subsection{Krama dalam Fungsi Sosial dan}

\section{Hukum}

Subbab di atas telah menjelaskan bahwa ajikrama lambang adat yang artinya nilai suci dari suatu strata sosial adat Sasak ini dibagi menjadi dua, yaitu:

1. Krama sebagai lembaga adat terdiri atas beberapa bagian, antara lain: a. Krama banjar urip pati, yaitu suatu kelompok adat atau perkumpulan masyarakat adat yang anggotanya terdiri atas penduduk di suatu kampung/dusun (dasan) atau berasal dari beberapa dasan, yang keanggotaannya berdasarkan dan mempunyai tujuan yang sama. Krama banjar lebih banyak bergerak pada banjar yang terkait urusan orang hidup dan orang yang mati. Jenisnya antara lain krama banjar subak, krama banjar merariq, krama banjar mate, dan krama banjar haji.

b. Krama Gubuk, yaitu bentuk krama adat yang beranggotakan seluruh masyarakat dalam suatu gubuk (dasan, dusun, kampung) tanpa kecuali. Keanggotaan krama tidak memandang bulu asalkan secara adat dan administratif yang bersangkutan adalah penduduk yang sah di dalam gubuk.

c. Krama Desa, yaitu majelis adat tingkat desa, terdiri atas pemusungan (Kepala Desa Adat), juru arah (Pembantu Kepala Desa), lang-lang desa (Kepala Keamanan Desa), jaksa (Hakim Desa), luput (Koordinator Kesejahteraan Desa), dan kiai penghulu. 
2. Krama sebagai aturan pergaulan sosial terdiri atas beberapa bagian, yaitu:

a. Titi Krama, merupakan adat yang diatur awig-awig sebagai hasil kesepakatan adat dari seluruh masyarakat adat. Jika dilanggar, dikenakan sanksi sosial atau sanksi moral seperti adat bejiran (bertetangga), adat nyangkok (menginap di rumah pacar).

b. Bahasa Krama, merupakan budi pekerti, sopan santun atau tata tertib adat yang diatur dalam awig-awig adat yang harus dilakukan dengan bahasa lisan dan bahasa tubuh yang santun dan tertib, dilakukan dengan penuh tertib-tapsila. Dalam bahasa krama terdapat beberapa kaidah dan tata bahasa yang termuat dalam kearifan lokal masyarakat Sasak, antara lain: tata bahasa, indit bahasa, rangin bahasa, peribahasa.

c. Aji Krama, merupakan harga adat komunitas atau juga harga status sosial seseorang atau nilai martabat kekerabatannya seseorang yang terkait dengan hak adat dalam komunitas, baik dalam lingkungan keluarga maupun dalam lingkungan masyarakat adat secara umum. Aji krama ini mencerminkan pengakuan terhadap status sosial sesorang dalam masyarakat.

Penerapan beberapa Krama dalam kehidupan etnis Sasak telah ikut mendorong lahirnya berbagai bentuk kearifan lokal dalam kumunitas tersebut yang mengandung nilai-nilai yang masih cocok dalam konteks kekinian dan relevan untuk diwariskan melalui pendidikan bagi peserta didik. Elaborasi berikut ini akan menyajikan pola-pola kearifan lokal yang dimaksud.

\subsection{Kategorisasi Bentuk Kearifan Lokal}

Secara umum, terdapat tiga kategori bentuk kearifan lokal suku Sasak Lombok, yaitu:

a. Bidang politik, sosial, kemasyarakatan, tercermin dari sebelas macam "saling" sebagai pengikat tali silaturrahmi masyarakat Sasak, yaitu: (1) saling jot/perasak (sama-sama saling memberi atau mengantarkan makanan); (2) saling pesilaq (sama-sama saling undang untuk suatu hajatan keluarga); (3) saling belangarin (sma-sama saling layat jika ada kerabat/sahabat yang meninggal); (4) saling ayoin (samasama saling mengunjungi); (5) saling ajinan (sama-sama saling menghormati atau saling menghargai 
terhadap pebedaan, menghargai adanya kelebihan dan kekurangan yang dimilki oleh seseorang atau kelompok tertentu); (6) saling jangoq (sama-sama saling silaturrahmi, menjenguk jika ada di antara sahabat sedang mendapat atau mengalami musibah); (7) saling bait (sama-sama saling ambil-ambilan dalam adat perkawinan); (8) saling wales/bales (sama-sama saling balas silaturrahmi, kunjungan atau semu budi /kebaikan yang pernah terjadi karena kedekatan-persahabatan); (9) saling tembung/sapak (sama-sama saling tegur sapa jika bertemu atau bertatap muka antar seorang dengan orang lain dengan tidak membedakan suku atau agama); (10) saling saduq (sama-sama saling mempercayai dalam pergaulan dan persahabatan) terutama membangun peranakan Sasak Jati (persaudaraan Sasak sejati) di antara sesama sanak (saudara) Sasak dan antar orang Sasak dengan batur luah (nonSasak); dan (11) saling ilingan/peringet (sama-sama saling mengingatkan satu sama lain antara seseorang (kerabat/ sahabat) dengan setulus hati demi kebaikan dalam menjamin persaudaraan/silaturahmi. b. Bidang ekonomi perdagangan, tercermin dari tiga macam saling sebagai praktik kearifan lokal, yaitu: saling peliwat (suatu bentuk menolong seseorang yang sedang pailit atau jatuh rugi dalam usaha dagangannya, saling liliq/gentiq (suatu bentuk menolong kawan dengan membantu membayar hutang tanggungan sahabat atau kawan, dengan tidak memberatkannya dalam bentuk bunga atau ikatan lainnya yang mengikat), dan saling sangkul/sangkol/sangkon (saling menolong dengan memberikan bantuan material terhadap kawan yang sedang menerima musibah dalam usaha perdagangan).

c. Bidang adat budaya, tercermin dari saling tulung (bentuk tolong menolong dalam membajak menggaru sawah ladang para petani); saling sero (saling tolong dalam menanami sawah ladang); saling saur alap (saling tolong dalam mengolah sawah ladang, seperti dalam hal ngekiskis/membersihkan rerumputan dengan alat potong kikis atau ngoma/ngomel mencabuti rumput; dan besesiru/besiru, yaitu nilai kearifan lokal ini juga hampir sama dengan saling saur alap, yaitu 
pekerjaan gotong royong bekerja di sawah dari menanam bibit sampai panen.

Di samping ketiga katagori tersebut, ada juga nilai-nilai kearifan lokal dalam komunitas Sasak yang memiliki signifikansi nilai dan sangat cocok diterapkan dalam kehidupan saat ini maupun di masa akan datang, yaitu nilai-nilai yang terdapat dalam ungkapan bahasa yang dipegang teguh dalam pergaulan sehari-hari dalam peribahasa dan pepatah sebagai perekat pergaulan masyarakat Sasak, yang dalam komunitas Sasak diistilahkan dengan sesenggak. Sesenggak yaitu ungkapan bahasa (tradisional) yang berbentuk peribahasa dan pepatah sebagai perekat pergaulan masyarakat Sasak.

Dalam sesenggak, banyak terkandung ajaran-ajaran dan nilai-nilai kearifan tradisional, seperti mengajarkan tentang ketuhanan, pendidikan, moral, hukum dan sebagainya. Beberapa contohnya antara lain

a. Adeqte tao jauq aiq (supaya kita dapat membawa air), maknanya bahwa dalam suatu perselisihan atau pertengkaran yang sedang terjadi dan memanas, maka kita harus mampu menjadi pendingin sebagai mediator

b. Besual/besiaq cara anak kemidi, (bertengkar seperti cara cara pemain sandiwara), maknanya boleh saja kita berselisih pendapat, tetapi tidak boleh menyimpan dendam.

c. Aiq meneng, tunjung tilah, empaq bau, (air tetap jernih, teratai tetap utuh, ikan pun dapat ditangkap), maknanya adalah bahwa dalam mengatasi dan menyelesaikan suatu perselisihan, diupayakan agar suasana tetap tenang, masyarakat tidak panik, lingkungan masyarakat tidak tertanggu, masalah atau perselisihan terselesaikan dengan damai.

d. Banteng belage jerami rebaq, (banteng yang beradu di tengahtengah sawah menyebabkan jerami rebah dan patah), maknanya adalah pertikaian yang terjadi pada dua orang pemimpin akan menyebabkan kesengsaraan dan penderitaan bagi rakyatnya. Hal ini diumpamakan dengan peristiwa yang terjadi di tengah-tengah sawah, jika diperhatikan, banteng, sapi, atau kerbau yang sedang beradu di tengah sawah yang baru selesai dipanen, keadaan jerami yang semula berdiri 
beraturan menjadi rubuh, jatuh tak tentu arah akibat pertarungan banteng tersebut. Demikianlah perumpamaan bagi pemimpin yang bertikai dan akibatnya bagi rakyat. Peribahasa ini ditujukan pada orangorang berkedudukan, baik dalam lingkup yang kecil maupun yang besar.

Berdasarkan uraian tentang kearifan lokal suku Sasak, mulai dari masalah krama sampai dengan sesenggak, dapat dirumuskan dan disimpulkan bahwa terdapat sepuluh unsur atau komponen nilai-nilai yang tercermin dalam kearifan lokal masyarakat Sasak, yaitu: (i) keimanan kepada Allah; (ii) sikap toleransi; (iii) kerja sama dengan orang lain; (iv) menghargai pendapat orang lain; (v) memahami dan menerima kultur masyarakat; (vi) berpikir kritis dan sistematik; (vii) penyelesaian konflik tanpa kekerasan; (viii) kemauan mengubah gaya hidup dan kebiasaan konsumtif; (ix) sensitif terhadap kesulitan orang lain; dan (x) kemauan dan kemampuan berpartispasi dalam kehidupan sosial.

\section{Metode Penelitian}

Pendekatan penelitian ini menggunakan metode kualitatif yang didasarkan pada pertimbangan untuk menjawab masalah dan tujuan penelitian, yaitu tentang Kearifan Lokal Suku Sasak Sebagai Model Pengelolaan Konflik Di Masyarakat Lombok.

Data-data yang digunakan dalam penelitian ini meliputi data primer dan data sekunder. Data primer terdiri atas dokumen-dokumen tentang kearifan lokal suku Sasak, hubungan antara Islam dengan budaya lokal dan hasil wawancara dengan para tokoh agama dan adat di pulau Lombok. Dalam penelitian ini, digunakan teknik wawancara mendalam (in-depth interview) dengan menggunakan pokok-pokok sebagai pedoman. Pokokpokok diperlukan agar wawancara tidak menyimpang dari fokus masalah penelitian untuk menghindari terjadinya kevakuman selama wawancara. Pokokpokok wawancara untuk masingmasing tidak selalu sama, sesuai dengan asumsi sebelumnya tentang keterangan yang dapat diperoleh dari informan yang bersangkutan.

Data penelitian ini berupa kegiatan kebudayaan dalam berbagai bentuk, misalnya lisan, tulisan, fisik, 
properti dan simbol-simbol budaya lokal. Selain itu, data penelitian ini berupa situs-situs keagamaan yang terkait dengan budaya lokal yang ada di daerah penelitian.

Karena penelitian ini bersifat kualitatif, analisis datanya bersifat iteratif (berkelanjutan) dan dikembangkan sepanjang penelitian berlangsung. Maksudnya, analisis data tidak dilakukan setelah pengumpulan data selesai, tetapi dilaksanakan mulai penetapan masalah, pengumpulan data dan setelah data terkumpul. Dengan demikian, peneliti dapat mengetahui kekurangan data yang harus dikumpulkan dan dapat mengetahui metode mana yang harus dipakai pada tahap berikutnya.

Dalam penelitian ini, analisis dilakukan secara induktif, yaitu peneliti berangkat dari fakta-fakta dan ketentuan-ketentuan yang bersifat khusus, kemudian dibuat generalisasi analisis sehingga dapat diambil simpulan yang besifat umum.

\section{Pembahasan}

\subsection{Model Pengelolaan Konflik Berbasis Kearifan Lokal}

Penyelesaian konflik seharusnya disesuaikan dengan konteks dan latar atau setting di mana konflik itu terjadi.
Dengan demikian, pendekatan yang umum sebenarnya tidak relevan diterapkan dalam menangani masalah konflik lokal sehingga dibutuhkan model khusus. Pendekatan dalam penyelesaian konflik yang belum banyak dikaji tetapi sebenarnya telah lama berjalan adalah kearifan lokal (local wisdom).

Pola penyelesaian konflik memang kadang unik, sehingga model di suatu daerah tak mungkin diterapkan di daerah lain. Oleh karena itu, dalam menentukan langkah penyelesaian berbagai peristiwa konflik perlu dicermati dan dianalisis banyak hal; tidak saja faktor global universal, tetapi perlu juga faktor lokal dan khusus. Penyelesaian konflik akan lebih tepat jika menggunakan model-model penyelesaian yang disesuaikan dengan kondisi wilayah serta budaya setempat. Penyelesaian yang ideal adalah jika dilakukan atas inisiatif penuh dari masyarakat bawah yang masih memegang teguh adat lokal serta sadar akan pentingnya budaya lokal dalam menjaga dan menjamin keutuhan masyarakat.

Tradisi dan kearifan lokal yang masih ada dan berlaku di masyarakat berpotensi untuk dapat mendorong 
keinginan hidup rukun dan damai. Hal itu disebabkan kearifan tradisi lokal pada dasarnya mengajarkan perdamaian dengan sesamanya, lingkungan, dan Tuhan. Pendekatan kearifan lokal sangat tepat dalam menyelesaikan konflik karena selama ini di samping sudah membudaya dalam masyarakat, kearifan lokal juga masih memiliki nilai sakral dan tidak hanya berorientasi profan semata. Dengan adat lokal ini, diharapkan resolusi konflik bisa selesai dan diterima secara damai oleh semua kelompok dalam waktu lama.

Selain argumen di atas, beberapa alasan lain pentingnya pendekatan kearifan lokal dalam mediasi konflik adalah karena kearifan lokal umumnya lebih menekankan nilai-nilai kemanusiaan, kebersamaan, persaudaraan, dan sikap ketauladanan, bukan pada nilai-nilai individual. Penyelesaian dengan resolusi konflik secara damai tidak meninggalkan rasa dendam dan sakit hati berkepanjangan, tetapi membangun emosi persaudaraan, rasa, nurani dan kehormatan diri. Oleh karena diselesaikan dengan rasional, pelibatan emosi dan perasaan, penyelesaian bersifat tuntas dan dapat diterima semua pihak yang bertikai. Di sinilah, resolusi konflik menawarkan kebersamaan atau sama-sama menguntungkan (win-win solution) bagi yang bersengketa dan tidak merugikan satu pihak, sementara pihak lain diuntungkan (win-lose solution).

Dalam konteks masyarakat suku Sasak di Lombok, Islam merupakan rujukan utama dan lensa ideologis dalam memahami dan mengevaluasi perubahan. Islam mempunyai peranan yang sangat penting dalam menghadapi perubahan serta kekuatan-kekuatan eksternal yang dirasakan sebagai ancaman terhadap kehidupan sosial mereka. Islam merupakan agama yang sangat dominan di pulau Lombok yang memainkan peran penting sebagai penjaga nilai-nilai kearifan lokal yang berkembang di masyarakat.

Pada masyarakat Sasak, kearifan lokal merupakan hal yang tidak dapat dipisahkan dengan agama dan adat budaya. Karenanya, denyut nadi kehidupan masyarakat Sasak memerlukan cara-cara yang arif lagi bijaksana. Karena itu, sikap yang etik yang dikembangkan masyarakat Sasak setidaknya juga tercermin dari petuah para orang tua yang dapat disimpulkan dalam ungkapan-ungkapan berikut: Solah mum gaweq, solah eam daet, bayoq mum gaweq bayoq eam daet 
(baik yang dikerjakan maka akan mendapat kebaikan dan buruk yang dikerjakan maka akan mendapatkan keburukan), piliq buku ngawan, semet bulu mauq banteng, empak bau, aik meneng, tunjung tilah. Masyarakat memahami bahwa seluruh alam raya diciptakan untuk digunakan oleh manusia dalam melanjutkan evolusinya hingga mencapai tujuan penciptaan. Kehidupan mahluk-mahluk Tuhan saling terkait. Bila terjadi gangguan yang luar biasa terhadap salah satunya, mahluk yang berada dalam lingkungan hidup akan ikut terganggu pula.

Berdasarkan aturan adat budaya ini, muncul budaya tradisional masyarakat Sasak yang tidak lepas dari pola trinitaris dasar yakni: pertama, “epe-aik" sebagai Pemilik yang Maha Kuasa atas segala asal kejadian alam dan manusia. Kedua, "gumi-paer" sebagai tanah tempat berpijak di situ langit dijunjung, karena di "gumi-paer" ini masyarakat Sasak dilahirkan, diberi kehidupan dan selanjutnya diwafatkan. Ketiga, "budi-kaye" yang merupakan kekayaan pribadi dari kesadaran akan "budi-daye" yang menurunkan "akalbudi" pada setiap diri manusia untuk mendapatkan kemuliaan hidup yang akan dibawa sampai meninggal dunia.
Ketiga hal inilah yang akan mewarnai setiap pandangan, ucapan, dan perbuatan masyarakat Sasak menjadi adab budaya yang tidak hanya diukur dengan hasil karya secara material, namun yang lebih penting adalah nilai-nilai yang diperoleh selama hidup yang tercermin dari pelaksanaan adat istiadat mereka (Sarjana, 2004).

Aspek kearifal lokal suku Sasak inilah yang perlu dielaborasi dan dieksplorasi secara komprehensif dan holistik sehingga terbentuk pola pemahaman tentang kearifan local yang terpadu, bersinergi, dan harmoni yang dimiliki masyarakat Sasak dalam hidup bermasyarakat sebagai model dalam mengeloala konflik yang melibatkan semua elemen masyarakat dan stake holder yang ada dalam masyarakat. Sementara itu, fenomena maraknya konflik sosial yang terjadi di masyarakat suku Sasak, baik di Lombok Barat, Lombok Tengah, Lombok Timur, dan Kota Mataram harus dilihat secara komprehensif. Fenomena konflik saat ini memang melanda hampir semua etnis masyarakat di Indonesia. Hal ini menjadi fenomena umum ketika saluran informasi dapat diakses secara masif, sehingga dapat membawa ekses kepada 
komunitas lain yang secara latah "ikutikutan" untuk mengekspresikan eksistensi identitas etnis atau kelompoknya.

Di samping itu, konflik juga dipicu oleh adanya ketimpangan sosial dan anomali moral dalam masyarakat. Hal inilah yang menyebabkan pada batas-batas tertentu tidak berfungsinya kearifan lokal secara maksimal sehingga perlu dilakukan upaya revitalisasi kearifan lokal dan reka cipta kearifan lokal baru (institutional development), suatu reka cipta kearifan lokal baru, yang tepat guna untuk menjawab tantangan sosial, ekonomi dan budaya, serta politik masa kini di masyarakat.

$$
\text { Rekomendasi perlunya }
$$
melibatkan "orang dalam" melalui kearifan lokal sebagai alternatif resolusi konflik sebetulnya bisa digunakan untuk kasus-kasus konflik bernuansa agama. Meskipun agama masih diperdebatkan sebagai unsur budaya atau bukan dalam konstruksi sosial masyarakat, fakta historis memperlihatkan bahwa proses integrasi dan harmoni di antara keyakinan yang berbeda yang pernah hidup di Indonesia dapat berlangsung justru karena kontribusi kearifan lokal dalam merawat dan mengelola perbedaan tersebut. Hanya saja, berbagai kearifan lokal yang mungkin dikembangkan di negeri ini masih saja membutuhkan apresiasi dan penguatan dari para elit agar kearifan lokal ini bekerja (workable) secara baik. Para pemimpin tradisional adalah penggerak yang menentukan harmoni sosial pada suatu komunitas.

Dalam komunitas Sasak, sejumlah kearifan nilai lokal sejatinya dapat dikembangkan sebagai upaya mengelola konflik dan membangun harmoni. Nilai-nilai kearifan lokal bisa dilacak dari naskah kuno Kotaragama, sesenggak (peribahasa), perteke, atau lelakaq (pantun). Berikut ini diketengahkan beberapa pantun (lelakaq) kearifan lokal Sasak yang memiliki makna luhur dalam membangun harmoni kedamaian untuk meredam konflik dan mengingatkan tentang tujuan akhir kehidupan untuk mendapatkan kebahagiaan dan keselamatan dunia-akhirat. Hal ini tergambar dari pantun (lelakaq) Sasak berikut ini:

Niniq Bai, Bije Sanaq Naken Bagus - bagus ntan jauq diriq endak langgar adat krama tertip tapsila endak piwal leq dengan towaq, pengelingsir leq pesware dengan si kwase silaq beriuk tunas ring arepan dekaji Allah 
Ta' ale Neneq si Kuase ampoq te jari dengan besanakan si tao jauq diriq Saleh-solah-soloh, Patut-patuh-pacu genem geger gerasak Lombok Mirah Saksaq Adi, sekadi siq tesurat leq dalam kitab negare kerta game maliq perlu te pade iling, Sai-sai juaq si te ican jari perkanggo endaq jari dengan si besifat bahil loba tamaq beterus betabeat angkuh iri dengki dait sombong ilingiling-iling beriuk pade iling.

Berdasarkan pantun tersebut, tergambar bahwa kedamaian dan harmoni sebetulnya merupakan kultur dominan masyarakat Sasak. Sejumlah idiom yang dikenal di lingkungan masyarakat Sasak sangat dekat dengan orientasi kedamaian. Konsep ajinin yang secara harfiah berarti saling menghormati, reme, rapah, regen, yang berarti suka memberi, memilih situasi aman damai dan mendukung toleransi menambah khazanah kearifan lokal masyarakat Lombok dalam menajalani relasi sosial.

Selain terdapat sejumlah petuah lama yang menjadi nilai-nilai luhur yang mengatur interaksi sosial di Pulau Lombok, terdapat pula banyak tradisi yang jika ditelusuri dapat menjadi bagian dari upaya bina damai (peace building). Tradisi-tradisi tersebut hingga kini masih dipraktikan di komunitas Sasak, terutama di daerah pedesaan. Hampir keseluruhan tradisi ini mengarah pada upaya menjaga harmoni sosial, seperti budaya roah atau begawe, yang berarti pesta. Dalam banyak kesempatan, roah dilakukan pada upacara kelahiran, pernikahan hingga kematian serta aktivitas perayaan hari-hari besar keagamaan, seperti Maulid Nabi dan Isra'-mi'raj. Tradisi ini dilaksanakan dengan cara sebuah keluarga biasanya memasak makanan dan mengundang tetangga, teman, atau sanak sadara untuk makan bersama. Mereka secara kekeluargaan melakukannya dengan cara duduk bersila melingkar dan bersama-sama menyantap makanan yang dihidangkan. Aktivitas ini biasanya disebut begibung (Suprapto, 2013).

Dalam begibung, semua orang duduk sejajar tanpa dibedakan status sosialnya. Mereka membaur menjadi satu dan dalam suasana penuh kekeluargaan. Meskipun sejumlah orang tokoh seperti tuan guru dan kiai biasanya memperoleh hidangan lebih awal ketimbang warga yang lain tetapi secara keseluruhan posisi mereka dalam proses begibung adalah sama. Menyantap makanan tanpa menggunakan sendok, semua orang merasakan menu masakan yang sama sambil bercengkerama secara lepas. 
Tradisi ini jelas menggambarkan adanya kerukunan dan keharmonisan di antara warga. Semangat menjalin silaturahim sangat kental dalam kegiatan ini.

Praktik kearifan lokal Sasak dalam bentuk institusi roah atau begawe ini merupakan institusi slametan yang berkaitan dengan kerukunan dalam kehidupan beragama. Kerukunan dan keselarasan menggunakan media slametan pada suku Sasak tercermin dalam slametan kelahiran anak, slametan kematian, slametan ibadah keagamaan seperti haji, slametan untuk menuntut ilmu dan rizki dan bermacam-macam bentuk slametan lainnya. Pada masyarakat suku Sasak, jika dalam acara slametan ini, maka tidak seorangpun merasa dibedakan dari orang lain.

Dengan adanya acara slametan masyarakat suku Sasak, akan dapat tercipta hubungan yang harmonis, tanpa adanya jarak antara orang per orang dan kelompok dalam komunitas masyarakat. Namun demikian, meskipun ada jarak dalam interaksi sosial kehidupan masyarakat suku Sasak --hal ini tidak dapat dipungkiri-, dengan slametan akan tetap terjaga keharmonisannya. Dengan slametan ini, masyarakat suku Sasak juga sadar dan tidak menutup mata jika kehidupan mereka memang berbeda dan mereka juga biasa memuji kepada orang-orang yang mampu menjaga diri dan keluarganya dari perbuatan-perbuatan tercela.

Di luar falsafah hidup yang dapat digali dari kearifan lokal tersebut, pada beberapa desa di Lombok, terdapat pula sejumlah aturan yang disepakati bersama oleh anggota masyarakat dan menjadi semacam hukum tak terlulis. Aturan yang disepakati bersama ini dinamakan awig-awig. Awig-awig, ada yang tertulis dan ada yang tak tertulis. Dalam praktiknya, awig-awig ini dapat lebih efektif dibanding hukum formal yang dikonstruksi negara. Rumusan awig-awig yang bersumber dari masyarakat dan dirumuskan secara partisipatif mendorong masyarakat dengan sukarela menaati dan menjaganya. Jadi, ketaatan yang muncul lebih karena kesadaran, bukan paksaan.

\subsection{Revitalisasi Prinsip Nilai Kearifan Lokal Suku Sasak}

Untuk memahami nilai budaya suku Sasak secara komprehensif, dibutuhkan pengertian dan pemahaman terhadap makna dari setiap perangkat 
simbolnya. Perangkat simbol yang bermakna ini dapat ditemui dalam berbagai sumber, seperti ungkapan dalam komunikasi sehari-hari, interaksi dan transaksi-transaksi adat, bait-bait pantun yang disebut "lelakaq" atau "lawas", petuah para orang tua (pengelingsir) yang disebut "wadi temah", dongeng-dongeng tradisional yang disebut "waran" atau "tuaran", dan perumpamaan-perumpamaan yang disebut "sesenggak". Selain itu, ada juga sumber-sumber tertulis, seperti naskah-naskah kuno, seperti lontar, babad, dan sebagainya.

\subsection{Prinsip-Prinsip Kearifan Lokal Suku Sasak}

Adapun prinsip-prinsip kearifan lokal suku Sasak dapat dirumuskan sebagai berikut.

1. Prinsip Kejujuran dan Kesetian Memegang Janji

Sifat tersebut di dalam Kotaragama disimbulkan dengan kata "danta" (gading gajah), "danti” (ludah), "kusuma" (bunga), "warsa" (hujan). Artinya, setiap kata-kata yang diucapkan atau janji-janji yang diikrarkan wajib dipegang dan dipertahankan dengan kuat bagaikan gading gajah yang apabila telah keluar tidak akan masuk lagi, jika berludah, tidak akan dijilat kembali, bagaikan bunga yang tidak akan mekar dua kali dan hujan jika telah turun tidak akan kembali naik. Sehubungan dengan ungkapan tersebut, sebuah sesenggak dalam bahasa Sasak mengatakan: "sampi betali isiq pepit, manuse betali isik raos", artinya "sapi diikat dengan seutas tali, sedangkan manusia diikat dengan kata-katanya".

2. Prinsip dalam Kepemimpinan

Dalam Kotaragama diatur macam-macam sifat yang terpuji antara lain, rakyat tidak boleh "nganut" (sekehendak hati), "sadu" (mengambil hak orang lain), "tahu” (bersifat mendua), "kawanten" (menyebarkan aib pimpinan), "jahil" (memfitnah pemimpin); setiap pemimpin terhadap rakyat haruslah bersifat seperti : "giri suci" (bagaikan sebuah gunung yang suci dan anggun), "surya" (matahari yang menerangi orang sebumi), "sasangka" (bulan yang bersinar lembut dan tidak dinyalakan), "jaladri" (bagaikan laut, menampung segala aspirasi), "bahni pawaka" (bagaikan api, tidak gentar menghadapi kezaliman), "nilatadu” (bagaikan langit, tetap pada keagungan). Ungkapan simbolik dalam sesenggak suku Sasak mengatakan "embe aning 
jarum, ito aning benang", artinya "kemana arah jarum ke situ arah benang" (rakyat taat kepada pemimpin yang adil), "pancing udang lain dait pancing tune", artinya "pancing udang, berbeda dengan pancing ikan tuna" (pendekatan terhadap orang dilakukan dengan cara yang sesuai dengan watak dan keadaannya), "tumpu mandi isiq penyadu", artinya "obat mujarab oleh kepercayaan" (pemimpin harus mendapat kepercayaan dari rakyatnya).

3. Prinsip dalam Menegakkan Ajaran Agama

Pengamalan hukum adat Sasak pada hakikatnya menghendaki setiap orang untuk selalu menjaga hubungan yang harmonis, baik antarsesama, maupun dengan alam sekitar. Semuanya harus dijalani dengan mengharapkan rida dari Allah Swt, Tuhan Semesta Alam. Hal ini tercermin dalam ungkapan-ungkapan antara lain: "Agama beteken lan betakaq adat", artinya "agama bertiang dan berwadah adat" (adat istiadat yang berlaku harus berfungsi menegakkan dan menyucikan agama), "ndaq ta ngaken barak api”, artinya "jangan kita makan bara api" (larangan untuk memakan riba), "pacupacu punik akherat", artinya "rajinrajin mencetak akhirat" (bersungguh- sungguh berbuat kebajikan), "rurung bender, turne gantar", artinya "jalan lurus lagi pula lebar" (kesejahtraan dan ketentraman hidup karena menuruti ajaran agama).

\section{Prinsip Kebersamaan dan Gotong Royong}

Kearifan lokal Suku Sasak sangat menjunjung tinggi kebersamaan dalam menjalani kehidupannya, baik di lingkungan keluarga, kerabat maupun di lingkungan yang lebih luas. Nilai kebersamaan dan gotong royong ini tercermin dalam berbagai ungkapan yang mengandung kearifan, antara lain :"Sorong jukung leq segara, bareng onyak bareng lenge", artinya "dorong perahu di laut, bersama-sama baik bersama-sama buruk" (jalankan hidup senasib dan sepenanggungan), "Sipat anak empaq, tao pesopok diriq", artinya "sipat anak ikan, bisa menyatukan diri" (perselisihan dan perbantahan harus dihindari). Ungkapan-ungkapan yang mengandung nilai kearifan dalam lelakaq Sasak, seperti "beriuk”, “beriuk tinjal", artinya "serempak, selangkah, seayun dalam bekerja", "reme", artinya "solidaritas dalam bekerja sama", "siru", artinya "saling berbalas dengan kebaikan". 
5. Prinsip Persamaan dan Kebersamaan Hak

Persamaan hak mengandung arti harkat kemanusiaan setiap orang harus dihargai dalam wujud mengakui, menghormati, dan menjalankan hakhak yang dimilikinya. Prinsip ini terlihat pada berbagai aspek dalam kehidupan, seperti dalam pengamalan hukum adat waris yang dikenal memiliki nilai-nilai kearifan, antara lain: harta warisan yang disebut "pusaka" disimbolkan sebagai "tolang daeng papuq baloq", artinya "tulang rusuk nenek moyang" (harta warisan itu meskipun "terbagi", pada hakikatnya tetap dianggap "tidak terpisah" dalam arti tetap dipandang sebagai "alat pemersatu" di kalangan para ahli waris). Harta warisan yang belum dibagi disebut "dowe tengaq", artinya "harta tengah" mengandung arti "hak dan kewajiban para ahli waris terhadap harta warisan adalah seimbang". Artinya nilai warisan yang diterima ahli waris sebanding dengan tanggung jawab atau kewajiban yang melekat padanya. Harta warisan (pusaka) yang sudah terbagi tetap dipandang tidak terpisah, tercermin dalam ungkapan/istilah "dowe sopoq", artinya "harta yang satu" (prinsipnya tetap saling terbuka untuk dinikmati bersama dan setiap ahli waris tidak bebas untuk memperalihkannya kepada orang di luar ahli waris). Jual beli dalam lingkungan keluarga dan kerabat tidak dilarang, tetapi fungsi harta warisan yang menjadi objek transaksi tetap sebagai media pemersatu, tidak boleh diabaikan. Hal ini tercermin dalam ungkapan "nemu sarat kepeng”, artinya "menerima warisan dengan syarat uang" dalam hal ini tidak dipergunakan istilah beli. Hal ini mengandung makna untuk tidak menghilangkan mata rantai pewarisannya.

Dalam memiliki harta benda, tidak boleh riya dan sombong karena harta yang dimiliki hakikatnya adalah milik Allah (“dowen Neneq"). Dalam pergaulan kemasyarakatan, orang Sasak tidak boleh menunjukkan keakuannya atas harta bendanya. Hal ini tercermin dalam ungkapan "dowen pelungguh saq leq tiang". Demikian pula dalam pergaulan antarsesama, sangat dijunjung tinggi falsafah tindih, maliq, dan matiq.

\section{Prinsip Kemanusiaan}

Martabat setiap orang harus dihargai dan dijunjung tinggi dalam arti setiap orang dijamin haknya untuk berkompetisi demi meningkatkan 
harkat dan martabat kemanusiaannya. Hal ini tercermin dalam ungkapan lelakaq Sasak "kaoq mondong jagung, sai tao jari agung", artinya "kerbau memikul jagung, siapa bisa jadi terhormat" (tanpa melihat asal usul dan simbol-simbol martabat individual, setiap orang mempunyai hak yang sama untuk meraih sukses). "ulah mandi isiq bisana", artinya "ular bertuah karena bisanya atau racunnya" (seseorang itu berharga atau berguna karena ilmunya). 7. Prinsip Pemeliharaan
Lingkungan

Dalam pemeliharaan lingkungan, baik bersifat fisik maupun nonfisik, kearifan lokal suku Sasak memberikan tuntunan yang sangat arif dan dilandasi keharusan bagi setiap orang untuk memiliki kesadaran yang tinggi. Pelaksanaan kewajiban tidak disebabkan rasa takut terhadap penguasa, atau pemilik saja, tetapi lebih dilandasi atas rasa takut terhadap komunitas dan di atas segala-galanya adalah takut kepada Allah Swt.

8. Prinsip dalam Perekonomian dan Etos Kerja

Setiap orang dituntut untuk selalu bekerja dengan penuh kesabaran dan keuletan. Setiap pekerjaan dilakukan dengan pertimbungan rasional.
Demikian halnya dengan hasil yang dicapai, tidak boleh dihamburhamburkan. Dalam konteks ini, ada beberapa nilai lokal yang berhubungan dengan prinsip ekonomi dan etos kerja tersebut, di antaranya : "Kendeq teteh sie leq segara", artinya "jangan buang garam di laut" (ini mengandung makna larangan melakukan pekerjaan sia-sia). Di dalam bekerja, setiap orang dituntut untuk cekatan yang disebut "kencak" dan rajin yang disebut "genem". Hasil yang diperoleh harus digunakan dengan hemat yang disebut "itiq", larangan berperilaku boros, diungkapkan secara simbolik "serut cina sampat besi", artinya "serut cina sapu lidi besi" (suka menghamburkan harta), karena perilaku hemat bisa menghantarkan orang menjadi kaya yang disebut "tomot".

Apabila orang telah meraih kehidupan berkecukupan (tomot), tidak boleh kikir dan tamak, tetapi harus dermawan yang disebut "lome". Setiap risiko dalam pekerjaan harus dihadapi dengan sabar "keduk lindung bani raok", artinya "mencari belut berani kena lumpur" (untuk mencapai tujuan dalam bekerja harus berani menanggung risiko). "Mesang ima naenta, bawaq lanjaq batur", artinya "ringankan tangan dan kaki kita agar 
tempat nasi teman menjadi rendah" (jika kita rajin, rezeki mudah didapat). Dalam mencari rezeki, jangan sekalikali memeras orang, "Kendeq nenggala leq atas bongkor batur", artinya “jangan membajak di atas punggung teman" (larangan mengambil keuntungan dari jerih payah orang lain). "nyuit isiq jaum", artinya "menyungkil menggunakan jarum” (ketekunan berusaha yang akhirnya membawa hasil). "sorok dampuk, bosang boros", artinya "sorok selalu menghasilkan, tetapi tempat penyimpanan bocor" (ketidakmampuan mengatur penghasilan). "tiwas karang jari apuh, manah tan keneng obah", artinya "biarpun batu karang jadi kapur, hati tidak boleh berubah" (harus memiliki ketetapan hati dalam memberikan pengorbanan demi memperjuangkan cita-cita).

9. $\begin{aligned} & \text { Prinsip dalam Penyelesaian } \\ & \text { Konflik }\end{aligned}$

Di dalam penyelesaian sengketa, kearifan lokal suku Sasak tidak menghendaki putusan kalah menang, akan tetapi harus mengarah kepada perdamaian yang diselesaikan dengan musyawarah mufakat. Dalam upaya penyelesaian itu, kedua belah pihak bisa saling menjaga perasaan masingmasing (tao saling undur pasang).
Dalam konteks upaya penyelesaian konflik ini, nilai kearifan lokal suku Sasak tercermin dalam ungkapanungkapan antara lain: "empaq bau, aiq meneng, tunjung tilah", artinya "ikan tertangkap, air tetap jernih, bunga teratai tidak rusak, tetap utuh". Maksudnya, dalam penyelesaian konflik harus diorientasikan untuk menghasilkan kepuasan kedua belah pihak, kedua belah pihak merasa menang dan tidak ada yang merasa kalah; "adeq ta tao jauk aiq", artinya "supaya kita bisa membawa air". Maksudnya, dalam suatu perselisihan, pertengkaran atau konflik yang memanas, kita mampu menjadi pendingin; "sifat anak empaq tao pesopoq diriq", artinya "sifat anak ikan bisa menyatukan diri”. Maknanya adalah mengandung nasihat untuk selalu menghindari berbantahan satu sama lain; "sikut tangkong leq awak mesaq", artinya "ukur baju pada badan sendiri”. Ungkapan ini mengandung makna bahwa segala perbuatan seseorang kepada orang lain, hendaknya diukur dengan ukuran pada diri sendiri.

Beberapa prinsip nilai kearifan budaya lokal suku Sasak inilah yang perlu direvitalisasi dan dieksplorasi 
secara komprehensif dan holistik, sehingga terbentuk pola pemahaman tentang kearifan lokal yang terpadu, bersinergi, dan harmoni yang dimiliki masyarakat Sasak dalam hidup bermasyarakat sebagai model dalam mengelola konflik yang melibatkan semua elemen masyarakat dan stakeholder dalam masyarakat. Oleh karena itu, dalam konteks revitalisasi kearifan local, dibutuhkan sebuah dialog yang tidak hanya memunculkan kelebihan masing-masing sambil merendahkan nilai yang lain, tetapi sebuah dialog yang sanggup menciptakan ruang heteroglosia, bersuara majemuk. Dialog bukan hanya percakapan atau pertemuan dua pikiran dan hati mengenai persoalan bersama, tetapi komitmen bersama yang tujuannya agar setiap partisipan dapat belajar dari yang lain, sehingga dapat berubah dan berkembang. Dengan demikian, paradigma dan sistem nilai sawa adalah menyangkut cara manusia melakukan perjumpaan dengan dan memahami diri sendiri dan dunia lain (the others) pada tingkat terdalam (from within), membuka kemungkinankemungkinan untuk menggali dan menggapai selaksa makna fundamental secara individual dan kolektif dengan berbagai dimensinya (Baidhawy, 2001).

\section{Penutup}

Demikianlah elaborasi tentang kearifan lokal suku Sasak yang sarat dengan nilai-nilai yang baik dan sesuai dengan norma-norma agama yang selama ini diyakini secara teguh oleh masyarakat Sasak. Aturan-aturan dan norma-norma ini telah lama terinternalisasi di masyarakat sehingga penghargaan dan penerimaan sebuah keputusan akan bertahan lama. Sejatinya, apa yang muncul dari hasil kesepakatan tersebut merupakan kehendak bersama masyarakat. Hal penting yang diperlukan adalah kesediaan dari para elit, baik elit agama (tuan guru, kyai), elit pemerintah, maupun elit adat untuk duduk bersama mengembangkan pola bina damai berbasis kearifan lokal. Kesediaan para elit terhadap prakarsa bina damai ini sangat penting karena meskipun sebuah daerah telah memiliki serangkaian nilai-nilai lokal dan mekanisme resolusi konflik, tetapi semuanya akan sulit berjalan tanpa keterlibatan elit secara aktif. Untuk itu, diperlukan penguatan di tingkat elit agar nilai-nilai kearifan lokal dapat dikembangkan menjadi 
bagian dari upaya resolusi konflik dan prakarsa perdamaian di masa depan.

Potensi kolaborasi revitalisasi kearifan lokal berbasis agama ini sangat mungkin dikembangkan tanpa harus bertabrakan dengan kaidah-kaidah Islam sebagai agama mayoritas masyarakat Lombok karena dalam Islam sendiri konsep seperti al- 'urf atau al-'addah muhakkamah merupakan konsep yang selama ini menjadi bagian dari sumber hukum. Pilihan penguatan dapat dilakukan dengan banyak cara sesuai kultur lokal, mulai dari kegiatan sangkep (pertemuan, seminar), dan gundem (musyawarah) yang difasilitasi oleh pemerintah atau lembaga swadaya masyarakat. Selebihnya, dalam bidang pendidikan, baik formal (sekolah, madrasah) maupun nonformal (pesantren), pengembangan kurikulum muatan lokal hendaknya memperhatikan kearifan lokal ini. Sebagaimana watak dari kearifan lokal sendiri yang merupakan sedimentasi dari proses dinamika masyarakat dalam kurun waktu yang lama, eksistensinya akan sangat tergantung dari kesediaan para aktor lokal dalam merawat dan mentransmisikan nilai-nilai tersebut dari generasi ke generasi.

\section{Daftar Pustaka}

Abdullah, Irwan, dkk (ed.).(2008). Agama dan Kearifan Lokal dalam Tantangan Global. Yogyakarta: Pustaka Pelajar.

Ayatrohaedi.(1986). Kepribadian Budaya Bangsa (local Genius). Jakarta: Pustaka Jaya.

Baidhawy, Zakiyuddin. (2001).“Membangun Sikap Multikulturalis perspektif Teologi Islam". Makalah pada Halqah Tarjih: Menuju Muslim Berwawasan Multikultural, 2001.

Fukuyama, F. (2002). The Great Disruption: Hakikat Manusia dan Rekonstitusi Tatanan Sosial. Yogyakarta: Qalam Press.

Ismail. (1990). Wawasan Jatidiri dalam Pembangunan Daerah. Semarang: Effhar dan Dahara Prize.

Ja'far, M.(2009). Agama dan Pergeseran Refresentasi: Konflik dan Rekonsiliasi di Indonesia. Jakarta: The Wahid Institute.

Kaplan, D. and Robert A, Manners. (1972). Culture Theory. New Jersey: Prentice Hall, Inc., Englewood Cliffs.

Koentjaraningrat. (1993). Manusia dan Kebudayaan di Indonesia. Jakarta: Penerbit Djambatan.

Marzali, Amri, dkk. (2003). Konflik Komunal di Indonesia Saat Ini. Jakarta: INIS 
Nasir, Mohamamd. (1998). Metode Penelitian. Jakarta: Ghalia Indonesia.

Sarjana, Agus. (2004). "Otokritik Islam dan Budaya Sasak Yang Mandul Mencegah Kekerasan" dalam Diskusi Publik "Peran Agama Dalam Mencari Solusi Kekerasan" Praya, 16 Februari 2004.

Sholahuddin, Marwan. "Mengenal Kearifan Lokal di Klepu Ponorogo: Praktik Hubungan Sosial Lintas Agama dan Mekanisme Pencegahan Konflik"

Sriyanto, Agus. (2012)."Resolusi Konflik Keluarga Berbasis Kearifan Lokal Islam Nusantara". Jurnal Analisis, Volume XII, Nomor 2, Desember 2012

Sriyanto, Agus. (2012)."Resolusi Konflik Keluarga Berbasis Kearifan Lokal Islam Nusantara". Jurnal Analisis, Volume XII, Nomor 2, Desember 2012

Suprapto. (2013). "Revitalisasi NilaiNilai Kearifan Lokal Bagi Upaya Resolusi Konflik". Jurnal Wali Songo, Vol.21, No. 1, 2013

Zada, Khamami, dkk.(2008).Prakarsa Perdamaian: Pengalaman dari Berbagai Konflik Sosial. Jakarta: Lakpesdam NU.

Zuhdi, Muhammad Harfin. (2015). Parokialitas Adat Wetu Telu: Dialektika Agama Lokal di Bayan Lombok. Mataram: Sanabil. 